\title{
Ultramorphological features of the egg of Telmatoscopus albipunctatus (Williston) (Diptera, Psychodidae)
}

\author{
Thalita Rochaํㅗ José Augusto de Oliveira David² \& Flávio Henrique Caetano ${ }^{3}$
}

\begin{abstract}
'Program de Pós-graduação em Ciências da Saúde, Universidade São Francisco, 12916-900 Bragança Paulista-SP, Brasil. tharocha@yahoo.com ${ }^{2}$ Laboratório de Citogenética, Universidade Federal do Pará, 66075-900 Belém do Pará-PA, Brasil. joseaugustodavid@hotmail.com ${ }^{3}$ Departamento de Biologia, Universidade Estadual Paulista, 13506-900 Rio Claro-SP, Brasil. fcaetano@rc.unesp.br
\end{abstract}

\begin{abstract}
Ultramorphological features of the egg of Telmatoscopus albipunctatus (Williston) (Diptera, Psychodidae). Psychodidae flies, also known as sewage, sand and filter flies are important for medical and veterinary purposes. General information about life cycle and adult habits is available, but few species are known about the egg morphology. Therefore, in this study, the egg ultramorphology of Telmatoscopus albipunctatus (Williston, 1893) was analyzed by scanning electron microscopy to describe its structure, generating data for further comparison between different fly species and genera. General aspects of T. albipunctatus egg are similar to other Psychodidae; egg measuring approximately $0.4 \mathrm{~mm}$ in length and $0.1 \mathrm{~mm}$ in width. However, based on the continuous and discontinuous longitudinal ridge sculptures observed on the exochorion, which can be species-specific, we can infer that $T$. albipunctatus eggs can survive under dry or moist conditions, making their control much more difficult. Our data emphasize the advantages of the electron microscope approach in the study of the exochorion patterns. Eggshell morphology of $T$. albipunctatus can be used as basis for further studies and as a tool to compare different species of Psychodidae flies.
\end{abstract}

KEYWORDS. Eggshell; exochorion; filter flies; ultramorphology.

\begin{abstract}
RESUMO. Aspectos ultramorfológicos do ovo de Telmatoscopus albipunctatus (Williston) (Diptera, Psychodidae). As moscas da família Psychodidae, também conhecidas como moscas de banheiro, são de importância médica e veterinária. Informações gerais sobre ciclo de vida e hábitos do adulto são facilmente encontradas, mas pouco se sabe sobre a morfologia do ovo. Dessa forma, neste estudo, a ultramofologia do ovo de Telmatoscopus albipunctatus (Williston, 1893) foi analisada por microscopia eletrônica de varredura com o objetivo de descrever sua estrutura, provendo importantes dados para futuras comparações entre moscas de diferentes espécies e gêneros. O aspecto geral do ovo de T. albipunctatus é similar a outros Psychodidae, medindo aproximadamente $0.4 \mathrm{~mm}$ de comprimento e $0.1 \mathrm{~mm}$ de largura. Entretanto, baseado nas esculturas contínuas e descontínuas do exocórion, as quais podem ser espécie-específicas, podemos inferir que os ovos de T. albipunctatus podem sobreviver sob condições de muita umidade ou seca, dificultando o controle da espécie. Nossos resultados ressaltam a importância do uso da microscopia eletrônica como uma ferramenta no estudo dos padrões do exocórion. A morfologia externa do ovo de T. albipunctatus pode ser usada como base para futuros estudos e como ferramenta para comparação de diferentes espécies de moscas do gênero Psychodidae.
\end{abstract}

PALAVRAS-CHAVE. Casca do ovo; exocórion; mosca de banheiro; ultramorfologia.

Psychodidae fly species, including moth flies and drain flies, Psychoda alternata Say, 1824; sewage flies, Psychoda cinerea Banks, 1894; sand flies, Lutzomyia spp.; and filter flies, Telmatoscopus albipunctatus (Williston, 1893), are found in many different habitats. Psychodinae adults are often found around sewage installations, as public washrooms, and Phlebotominae adults occur often near water in dry-semi-arid areas, tropical forests and savannas (Maciel \& Missawa 2009; Rêgo et al. 2007). Household and general urban environment are favorable for the immature stages, which live in organic sludge, animal burrows, termite hills, tree holes and leaf litter, and this development facilitates the Psychodidae transition from the natural to the human environment (Robinson 1996).

Psychodids have medical-veterinary significance because their adult forms can act as vectors of bacteria and other microorganisms (e.g., protozoans), and larvae can cause myiasis (Costa et al.1998; Tu et al. 2007), or generate bronchial asthma in people who accidentally inhale fragments of their disintegrated body parts (Robinson 1996). Larvae (stages II, III and IV) and pupae of $T$. albipunctatus, for example, were found in colonies of the wasp Agelaia panamaensis (Cameron, 1906), suggesting that these flies may occasionally parasitize other insects (Hunt et al. 2001).

Life cycle of Psychodidae includes the stages of egg, larvae and pupae, being completed in one to three weeks and the adult forms can live about two weeks after emerging. An adult female lay from 30 to 200 eggs which hatch in less than 48 hours into small ( $3 / 8$ inch), legless larvae that are pale in the middle and darker on the ends. Eggs are tiny, brown or cream-colored and are laid in moist shady areas outdoors such as bird feeders and baths, under potted plants and air conditioners or on wet ground areas (Robinson 1996; Redborg et al. 1983). The major diversity of Psychodidae species is observed after a rain season, although the greatest number of individuals for species was observed during the dry period (Rêgo et al. 2007). 
General aspects of egg morphology are similar to different species of Diptera, including Psychodidae. However, the chorionic sculpturing, the posterior pole and the aeropyle, when observed under Scanning Electron Microscopy (SEM), are important tools to differentiate among species.

In some Lutzomyia species, the chorionic sculpturing can present a series of columns arranged in palisade to form sinuous longitudinal ridges with a few cross-ridges defining rectangular areas with different sizes, giving to the egg surface a reticular pattern, or columnar ridges defining elliptical areas, which are crossed by transverse fine ridges to form irregular quadrilaterals, attributing to the eggshell surface a polygonal pattern. On these eggs the basal layer, in interridge area, is covered with fibrous material or has rounded corners. While in other species, the chorion consists of a uniform layer of numerous and regularly disposed high mountain volcano-like structures (Fausto et al. 2001).

The posterior pole is constituted by few chorionic ridges protuberances of different sizes, divided or not into two semicircular areas, or devoid of the structures characterizing the rest of the egg surface. For some species of Sergentomyia and Lutzomyia, the posterior pole is not well defined and the area is covered by several protuberances distributed around the two aeropylar openings. The aeropylar opening can also present several small conical protrusions or uneven ridges (Fausto et al. 1993, 2001).

All these morphological characteristics have been used by taxonomists (ootaxonomy) as reliable markers to differentiate related species of insects, specifically Diptera species (Hinton 1981). With regard to the filter flies, studies on eggshell morphology have been delayed by the difficulty of finding eggs in nature. Study of eggs of T. albipunctatus using SEM is an important tool to characterize the eggshell morphology of this species, providing information to differentiate them from eggs of other health hazard species of Psychodidae.

\section{MATERIAL AND METHODS}

Adults of Psychodidae were individually collected in Rio Claro and São Paulo cities (São Paulo state, Brazil), and maintained isolated in small vials with damp filter paper for oviposition. Specimens were placed in refrigerator $\left(4^{\circ} \mathrm{C}\right)$ and identified as T. albipunctatus, based on hair color and number of segments present in the antennae, according to the taxonomic key of Forattini (1973).

The filter papers were checked under stereomicroscope each hour after the adults capture. Approximately 20 newly laid eggs naturally obtained were fixed in paraphormaldehyde $4 \%$ for 48 hours, and dehydrated in a crescent series of acetone $(70,80,90$, and $100 \%)$ for 10 minutes each concentration. After being taken to the critical point drying (Balzer CPD 030) for a complete desiccation, the eggs were mounted on stubs coated with sticky tape, sputter-coated with gold (Sputtering Balzer SCD 050) and observed under SEM (Philips, United States).

\section{RESULTS}

Eggs of T. albipunctatus are oval and curved, measuring approximately $0.4( \pm 0.03) \mathrm{mm}$ in length and $0.1( \pm 0.02) \mathrm{mm}$ in width $(\mathrm{n}=20)$ (Fig. 1).

The ventral and dorsal egg surfaces present the same pattern of sculpture over the exochorion. These imprints, obtained during the chorion formation, have a parallel arrangement of continuous and discontinuous longitudinal ridges, distant $125 \mu \mathrm{m}$ from each other, determining a porous inter-ridges area with depressions which may be perforations or not (Fig. 2). At the anterior pole, a circular micropylar apparatus is observed. This structure shows two perforations surrounded by 7-8 triangular cellular impressions (Fig. 3). Channels are observed separating these impressions, but they are not continuous with any other structures of the exochorion (Fig. 4). In the posterior pole, the same structures observed along the exochorion are also present (not shown).

\section{DISCUSSION}

Eggshell sculptures, produced by follicular epithelial cells (follicle), are considered to be species-specific, and have been used as a diagnostic character for species identification. However, there are few studies on egg morphology based on electron microscopy, which makes it difficult and, at the same time, very important to perform comparative studies within Psychodidae and even other fly species.

Three different categories of chorionic patterns were proposed by Ward \& Ready (1975): "volcano-like or mountainlike", "polygonal", and "parallel ridging", which was latter subdivided by Endris et al. (1987) into "connected ridges" and "unconnected ridges". Recently, other chorionic patterns were discovered, including: "elliptical" (Feliciangeli et al. 1993), "verrucose” and “disperse” (Pérez \& Ogusuku 1997). "Unconnected ridges" were also subdivided into two categories: "fragmented chained" and "complete chained" (Gebre-Michael \& Lane 1991). The latter one was defined as "reticular" by Fausto et al. (1992).

The general morphology of T. albipunctatus egg based on SEM is similar to some other Psychodidae species previously studied, such as Lutzomyia longipalpis (Lutz \& Neiva, 1912) and L. cruzi (Mangabeira Filho, 1938) (Almeida et al. 2004).

In T. albipunctatus, the hexagonal exochorion pattern (determined by the presence of longitudinal ridges continuously and non-continuously through the entire egg surface in the dorsal and ventral faces) is distinct from those categories. Most patterns have prominent ridges consisting of one ( $L$. migonei (França, 1920); Almeida et al. 2004) or more series of columns (Phlebotomus sp.; Fausto et al. 1992) which were not observed in T. albipunctatus, whose eggs are morphologically uniform as Sergentomyia (Fausto et al. 1993).

The perforated inter-ridge areas on T. albipunctatus, as Sergentomyia (Fausto et al. 1993), differs from those covered 

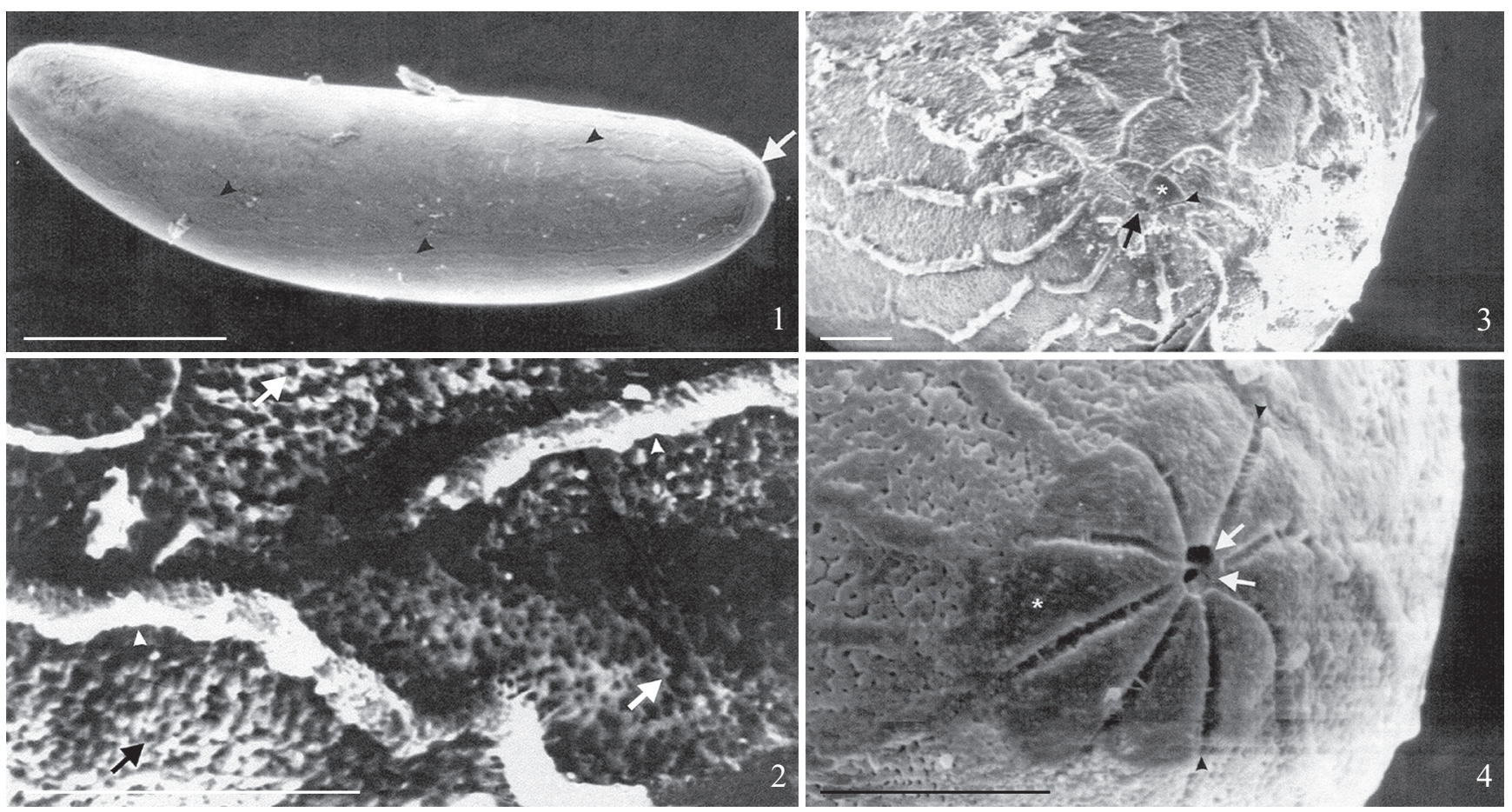

Figs. 1-4. SEM micrograph of T. albipunctatus egg: 1, showing the micropylar apparatus (white arrow) and the longitudinal ridges (black arrowheads); 2 , eggshell surface displaying the porous exochorion (black arrow), non-perforated areas (white arrows) and the longitudinal ridges (white arrowheads); 3, anterior pole: the micropylar apparatus (black arrow) and the follicular epithelial cell impressions (white asterisk) separated by single channels (arrowheads); 4, enlargement of micropylar apparatus showing two openings (white arrows), triangular cellular impressions (white asterisk), and channels (black arrowheads). Scale bars: $1=0.1 \mathrm{~mm}, 3-4=10 \mu \mathrm{m}$.

fibrous observed on L. ovallesi (Ortíz, 1952) and L. absonodonta Feliciangeli, 1995 (Fausto et al. 2001).

Eggs of some other dipterans, such as Anopheles sp., present projections on the interface (ventro-lateral) responsible for the egg floating (Wolf \& Guanchun 1996; Forattini et al. 1997, Valle et al. 1999). This same function is attributed to the volcano-like protuberances described for $L$. panamensis, which is more abundant in damp microhabitats (Ward \& Ready 1975; Almeida et al. 2004). In this case, the prominent structures protect the aeropylar openings, being basis for a well developed plastron (an area for gas exchange).

The aeropyles allow free exchange of oxygen and carbon dioxide and minimizes water loss from eggshells (Hinton 1970) permitting respiration under dry conditions (Margaritis 1985). However, it is hard to distinguish functionally the aeropyles from the plastron-bearing holes since it is almost certain that in most cases the aeropyles holes establish a plastron interface upon immersion of the egg in water (Margaritis 1985).

Volcano-like structures protect the aeropylar openings and are probably the bases for a well developed plastron, reflecting its damp habitats preference (Fausto et al. 2001). However, the presence of a perforated exochorion allows T. albipunctatus egg to survive in dry conditions (aeropyle), and under a moist condition, in which those openings work like a plastron.

Some authors attribute to the micropylar morphology a taxonomic feature in insects (Hinton 1981; Margaritis 1985; Valle et al. 1999). The morphology of the anterior pole and the presence of the micropylar apparatus, described in $T$. albipunctatus, are similar to that observed for Melipona bees (Cruz-Landim \& Yabuki 1995). The multiple openings observed in $T$. albipunctatus (two openings) suggest a mechanism of poly sperm, not clearly elucidated until the moment (Margaritis 1985).

All the data presented in this paper elucidates the eggshell morphology of T. albipunctatus in details, which was observed under stereomicroscope only, emphasizing the importance of using SEM as a tool to ootaxonomic studies comparing different species of Psychodidae flies.

\section{ACKNOWLEDGEMENTS}

The authors thank to Dr. Cláudio José Von Zubben for help in the identification of adult Psychodidae and to Department of Biology (UNESP) for technical support.

\section{REFERENCES}

Almeida, D. N.; R. S. Oliveira; B. G. Brazil \& M. J. Soares. 2004. Patterns of exochorion ornaments on eggs of seven South American species of Lutzomyia sand flies (Diptera: Psychodidae). Journal of Medical Entomology 41: 819-825.

Costa, J. M. L.; L. S. Melo; I. Figueiredo; R. Cipriano; S. L. Sousa; F. Fernandes \& M.L. Rodrigues. 1998. Leishmaniose cutânea difusa (Lcd) no estado do Maranhão, Brasil: relato de dois casos novos. Revista da Sociedade Brasileira de Medicina Tropical 31: 114-220. 
Cruz-Landim, C. \& A. T. Yabuki. 1995. Fine structure and morphogenesis of the micropyle apparatus in bee eggs. Biocell 19: 125-132.

Endris, R. G.; D. G. Young \& P. V. Perkins. 1987. Ultrastructural comparison of egg surface morphology of five Lutzomyia species (Diptera: Psychodidae). Journal of Medical Entomology 24: 412-415.

Fausto, A. M.; M.D. Feliciangeli; M. Maroli \& M. Mazzini. 2001. Ootaxonomic investigation of five Lutzomyia species (Diptera, Psychodidae) from Venezuela. Memórias do Instituto Oswaldo Cruz 96: 197-204.

Fausto, A. M.; M. Maroli \& M. Mazzini. 1992. Ootaxonomy and eggshell ultrastructure of Phlebotomus sandflies. Medical and Veterinary Entomology 6: 201-208.

Fausto, A. M; M. Maroli \& M. Mazzini. 1993. Scanning electron microscopical study of the eggshell of three species of Sergentomyia (Diptera, Psychodidae). Insect Science and its Application 14: 483488.

Feliciangeli, M.D.; O.C. Castejon \& J. Limongi. 1993. Egg surface ultrastructure of eight New World phlebotomine sandfly species (Diptera: Psychodidae). Journal of Medical Entomology 30: 651-656.

Forattini, O.P. 1973. Entomologia Médica. São Paulo, Editora USP, 658 p.

Forattini, O. P.; M. A. M. Sallum \& D. C. Flores. 1997. Description of the egg of Anopheles (Anopheles) intermedius (Peryassu, 1908) (Diptera: Culicidae) by scanning electron microscopy. Revista do Instituto de Medicina Tropical de São Paulo 39: 5-10.

Gebre-Michael, T. \& R. P. Lane. 1991. Scanning electron microscopy of eggs of Phlebotomus (Synphlebotomus) martini and P. (Syn.) celiae (Diptera: Phlebotominae). Parassitologia 33: 261-266.

Hinton, H. E. 1970. Insects eggshells. Scientific American 223: 84-91.

Hinton, H. E. 1981. Biology of insect eggs. Oxford, Pergamon Press, 473 p.

Hunt, J. H.; S. O’Donnel; N. Chernoff \& C. Brownie. 2001. Observation on two neotropical swarm-founding wasps, Agelaia yepocapa and $A$. panamaensis (Hymenoptera: Vespidae). Annals of Entomological Society of America 99: 555-562.

Margaritis, L. M. 1985. Structure and physiology of the eggshell, p.153230. In: G. A. Kerkut \& L. I. Gilbert (eds.). Comprehensive insect physiology biochemistry and pharmacology. Embryogenesis and reproduction. Oxford, Pergamon Press, vol. 1, 487 p.

Maciel, G. B. M. L. \& N. A. Missawa. 2009. Fauna flebotomínica (Diptera: Psychodidae) em aldeias indígenas do estado de Mato Grosso. Revista da Sociedade Brasileira de Medicina Tropical 42: 597-602.

Perez, E. J. \& E. Ogusuku. 1997. Chorion patterns on eggs of Lutzomyia sand flies from the Peruvian Andes. Medical Veterinary Entomology 11: $127-133$.

Redborg, K. E.; T. D. Hinesly \& E.L. Ziegler. 1983. Rearing Psychoda alternata (Diptera: Psychodidae) in the Laboratory on Digested Sewage Sludge, with Some Observations on Its Biology. Environmental Entomology 12: 412-415.

Rêgo, R.L.; R.S. Fonteles; G.C. Vasconcelos; P.C.B. Azevedo; K.S. Lobato; C.L.C. Santos; L.C. Rosa; F.S. Rodrigues; J.L.P. Moraes; Y.N.O. Pereira \& J.M.M. Rêbelo. 2007. Estudo eco-epidemiológico de flebotomíneos (Diptera, Psychodidae) do município de Axixá, área endêmica de leishmaniose tegumentar americana no Maranhão, p.1-2. In: Anais do VIII Congresso de Ecologia do Brasil. Available from: http://sebecologia.org.br/viiiceb/pdf/448.pdf. (access 09/09/2010).

Robinson, W. H. 1996. Fly pests in indoor and household environments, $p$. 293-295. In: W. H. Robinson (ed.). Urban entomology: insect and mite pests in the human environment. London, Chapman and Hall, $430 \mathrm{p}$.

Tu, W. C.; H. C. Chen; K. M. Chen; L. C. Tang \& S. C. Lai. 2007. Intestinal myiasis caused by larvae of Telmatoscopus albipunctatus in a Taiwanese man. Journal of Clinical Gastroenterology 41: 400-402.

Valle, D.; A. T. Monnerat \& M. J. Soares. 1999. Mosquito embryos and eggs: polarity and terminology of chorionic layers. Journal of Insect Physiology 45: 701-708.

Ward, R. D. \& P. A. Ready. 1975. Chorionic sculpturing in some sand fly eggs (Diptera, Psychodidae). Journal of Entomology 50: 127-134.

Wolf, K. W. \& L. Guanchun. 1996. Fine structure of the egg-shell in two flies, Megaselia scalaris and Medaselia spiracularis (Diptera: Phoridae). International Journal of Insect Morphology and Embryology 25: 289-294.

Received 28/1/2010; accepted 14/4/2011

Editor: Silvio Shigueo Nihei 